\title{
CONCERNING CERTAIN CELLULAR ELEMENTS IN THE COELOMIC CAVITIES AND MESENCHYMA OF THE MAMMALIAN EMBRYO
}

\author{
V. E. EMMEL \\ From the Anatomical Department, Washington University Medical School and the \\ Institute of Anatomy, University of Strassburg \\ FOUR PLATES (FORTY-FOUR FIGURES)
}

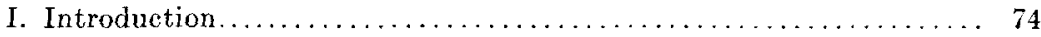

II. Occurrence and distribution of the free cellular elements in the $\mathrm{cm}-$ bryonic coelom................................. 74

III. The eoelomic macrophags

1. Cytological characteristics ..................... 76

2. Evidence as to their origin from the coelomic mesothelium ..... 81

a. Certain characteristics of the coelomic mesothelium in general. .............................. 81

b. Free mesothelial cell masses in the coelomic cavities...... 84

c. The mesothelium of the pleuro-pericardial and pleuroperitoneal membranes ...................... 85

IV. Erythrocytic elements in the coelomic cavities ............. 87

1. Small eosin staining bodies ..................... 88

2. Nucleated erythrocytic cells .................... 90

V. Erythrocytic disintegration in the mesenchyma ............. 93

1. Degenerative changes in erythrocytic nuclei with reference to ... 93

a. The question of the mesenchymal secretion of erythrocytic elements............................ 93

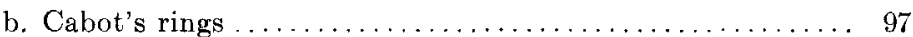

2. Degenerating erythroblasts and the so-called eosinophilic leucocytes of the embryonic mesenchyma . . . . . . . . . . . . 99

VI. Concerning the present status of the question as to the origin of mat-

rophags from the coclomic mesothelium.................. 103

1. Embryological and comparative................... 103

2. In adult mammals............................. 104

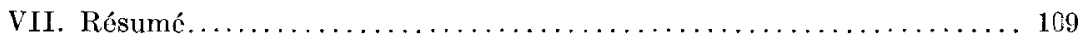

VIII. Literature cited...................................... 113 


\section{INTRODUCTION}

The following study is concernad with the free cellular elements in the pericardial, pleural and peritoneal body cavities. The results of recent morphological as well as experimental and clinical investigations regarding the nature and origin of these structures as they occur in the serous cavities of the adult mammal are of a divergent character. In view of this fact together with the apparently entire absence as yet of embryological data bearing on the problem, it has appeared desirable to obtain if possible more definite information as to the cytological conditions in the coelomic cavities of the embryo. The nature of the present subject has also necessitated the extension of the study to include certain cellular structures occurring in the embryonic mesenchyma.

Part of the following study was made while at the University of Strassburg during a leave of absence from the Washington University Medical School. I wish to express my indebtedness to Prof. G. Schwalbe for the generosity with which the facilities of the Anatomical Institute were placed at my disposal and the encouraging interest taken in the work by Prof. Franz Weidenreich. It is with regret that in consequence of the present disrupted political condition in Europe it has been necessary to forego the pleasure of Professor Weidenreich's valued criticism of the final results of the research.

II. OCCURRENCE AND DISTRIBUTION OF THE FREE CELLULAR ELEMENTS IN THE EMBRYONIC COELOM

The presence of free cellular elements in the embryonic body cavities were first noted in a $7.4 \mathrm{~mm}$. pig embryo. In order to ascertain to what extent these elements were normally present, the observations were subsequently extended to include the following material: 5 to $12 \mathrm{~mm}$. pig embryos, $9 \mathrm{~mm}$. rabbit embryos, 5 to $9 \mathrm{~mm}$. mouse embryos and several $9 \mathrm{~mm}$. opposum embryos. The specimens were fixed in Zenker-formalin (Helly's modification), embedded in celloidin or paraffin and the serial 
sections stained with Giemsa or Azur-Eosin in accordance with the technique developed by Maximow.

In the study of these cellular elements as they occur in the per:cardial, pleural and peritoneal cavities, the following precautions are to be taken into account. In the case of early embryos in which the peritoneal cavity is still in communication with the extra embryonic coelom, if the umbilical cord has been cut previous to fixation there is present the possibility of an accidental entrance of external elements into the peritoneal cavity through the cut cord during the fixation and removal of the embryo from the uterus During the necessary manipulation of staining and mounting, extra coelomic blood and tissue cells may become accidentally detached and transferred to the coelomic areas of the section. In the present study in the case of a doubt as to confusion with such dislocated cells the data was either discarded or recorded with a question mark. In the majority of cases, however, erroneous data arising from such sources can be satisfactorily eliminated by confining the evidence to such cells or groups of cells which can be demonstrated to extend through two or more successive sections in the series, or are clearly embedded in the coagulum of the serous fluid. The results of such a critical study seem to leave no doubt as to the normal and constant occurrence of a considerable number of free cellular elements (somewhat variable perhaps in quantity) in the body cavities of the mammalian embryo.

These free cells are irregularly distributed throughout the serous fluid. At certain stages of development, i.e., previous to the closure of the pleuro-pericardial and pleuro-peritoneal canals, they may be especially abundant in the region of the developing pleuro-pericardial and pleuro-peritoneal membranes In general they are not infrequently found relatively more numerous and aggregated at one side or another of the cavity, a condition no doubt due in part to the settling of the coelomic fluids and their cellular content toward one side of the body during fixation, as is not infrequently observed in the case of the blood in the heart and blood vessels. 
In the following account the coelomic cellular elements found in the present material may, on the basis of their cytological and functional characteristics, be conveniently described as falling into two groups: first, the basophilic staining and usually phagocytically active cells, which, as will become more evident in the ensuing description, may be designated as the coelomic macrophags; and second, cellular elements characterized by their eosinophilic staining qualities and nonphagocytic activity.

\section{THE COELOMIC MACROPHAGS}

\section{Cytological characteristics}

The majority of the free coelomic elements are embraced in the first of the above indicated groups. These basophilic cells may be further roughly subdivided into three types which may be described as follows:

The first of these types is illustrated in figures 1, 2, 9 and 14 icm. These cells are more or less spherical in form and somewhat smaller in size than those of the other two types. The nucleus varies from a central to an eccentric position within the cell, and may be either round or more or less indented on one side, so as to approximate a kidney shape. The cytoplasm is typically basophilic in staining reaction, is without any specific granular structure and may occasionally contain several small vacuoles. In form, size, nuclear and cytoplasmic structure these cells appear comparable to certain phagocytic cells oceurring in the embryonic circulation of the same embryos. The cells of the second type are illustrated in figures 4, 5, 6, 8b, 10, $14 \mathrm{pcm}$. They are as a rule larger in size and more oval or irregular in contour. The nuclei are quite eccentric in position and as a rule more flattened and kidney shaped in form. The cytoplasm usually takes a much lighter basophilic stain. A distinguishing characteristic is the phagocytic inclusions contained in the cytoplasm. These inclusions consist almost entirely of nuclei and cell bodies at various stages of intracellular digestion. It is of interest to note that these inclusions consist largely of red staining or apparently erythrocytic elements. The majority of the 
free cells of the coelomic cavities belong to this second class. Cells of the third type are illustrated in figures $14 \mathrm{vcm}$. and 13 . The chief characteristic is that of the highly vacuolated condition of the cytoplasm. The rounded or flattened nucleus is eccentric in position. Not infrequently cytoplasmic knobs or buds are observed projecting from the surface of the cell (figs. 14 and 44). These cytoplasmic buds may vary considerably in intensity of stain but in all the cases observed they were basophilic in their stain reaction. The relation of some of these buds as partially if not entirely detached from the cell (fig. 44b), together with the occasional occurrence of apparently similar basophilic bodies free in the coelomic fluid, indicates the possible constriction off of these cytoplasmic processes from the parent cell. If such is the case the phenomenon appears comparable to the liberation of detached portions of the cytoplasm as described by Weidenreich, '12, p. 2602 (also Downey and Weidenreich, '12, and Downey, '12).

The question now arises as to whether these cell types represent genetically distinct kinds of cells or whether these cells are more or less closely interrelated structurally and functionally. In attempting to answer this question from sectioned material, we are necessarily largely dependent upon such evidence as can be obtained by a comparative cytological study, and endeavoring to ascertain the occurrence or absence of data indicative of structural intergradations between the cells in question. In the course of such a study the following results were attained. Attention has already been directed to the fact that a chief distinguishing characteristic of the second type of cells is that of the phagocytic ingestion of other cell bodies. In comparing cells $i \mathrm{~cm}$ and $\mathrm{pcm}$ in figure 14 as representative of the first two groups just described, a considerable size difference is at once evident. It may be questioned, however, whether this is not largely a result of functional activities. The ingestion of cell bodies may be expected to increase the cell size and this is what is actually found, for the coelomic macrophags containing three, four or more cellular inclusions are larger than those having only a single inclusion, as may be observed for example in 
figures 4,5 and 6 . Cells with a single inclusion usually do not differ greatly in size from those of the first group. Reddish staining bodies, corresponding apparently to centrospheres, may be found in both types (figs. 1 and $8 a$ ) although less frequently observed in the more highly phagocytically active cells. The flattened or more kidney shaped form and more eccentric position of the nucleus in the cells of second type is evidently largely due to the bulging out of the cytoplasm, as the result of the ingestion of the cellular inclusions and a correlated eccentric displacement of the nucleus toward the opposite side or pole of the cell body. Between these two cell types a striking difference in the intensity of basophilic stain may also be frequently noted. The present data, however, warrants the conclusion that these staining differences are correlated to an important degree with functional activities. All gradations are to be observed between the strongly basophilic cells, figures $1,2,9,14 \mathrm{icm}$ and the pale staining cells in figures $6,10,14 \mathrm{pcm}$. Furthermore, it appears of significance that the macrophags containing the larger number of cellular inclusions are almost always the paler in cytoplasmic stain. After the study of a large number of these cells one is impressed with the suggestion that this may, in part at least, be a direct result of intracellular digestive functions. Certainly there can be no question but that the digestive chemical interactions between the phagocyte and cellular inclusion, whatever their exact nature may be, are of such a character as to change the ingested erythrocyte from a bright red staining cell to a practically colorless non-staining mass (figs. 5, 6, and 8). In case of an ingested erythroblast the erythrocytic nucleus may first become fragmented (figs. 4 and 5) or else manifest progressive changes from center toward its periphery (figs. $6 n$ and $33 e$, also p. 95), but in either case it eventually experiences a practically complete loss of its staining properties. On the other hand, however, may not this digestion also involve correlated changes in the staining substances of the phagocytic cell? The frequent association of a pale staining cytoplasm with maximum phagocytic activity strongly indicates that this is the case. If this conclusion is correct it offers an explanation for the basophilic differences between the two types of cells under consideration. 
No evidence was obtained as to the exact nature of this change in the staining qualities of the cytoplasm of the phagocytewhether it is the result of an internal absorption of digestion products or whether it is due to a modification or reduction of cytoplasmic elements of the phagocyte itself as they participate in the digestive processes. In either case it is remarkable how constant and sharp is the demarkation between the cytoplasm of the phagocyte and that of the ingested cell, and that one is able to detect little if any difference in the cytoplasm of the phagocyte in the immediate vicinity of the inclusion as compared with that in the more remote parts of the same cell body. It is to be observed that these color changes in the phagocyte are apparently not confined exclusively to its cytoplasm for the nucleus also may become much lighter in the highly active macrophags, a change involving apparently the nucleoplasm rather than the chromatin (cf. figs. 1, 2, 9 and $14 \mathrm{icm}$, with 5 , 6,10 , and $14 \mathrm{pcm}$ ). These cytoplasmic and nuclear differences appear especially well demonstrated in figure 8 . These two cells frcm the pericardial cavity of a $9 \mathrm{~mm}$. pig embryo were lying side by side in the manner drawn. Consequently there can be no question of variation in fixing or staining technique as factors in their staining differences. In $(a)$ both nucleoplasm and cytoplasm are quite basophilic, while in $(b)$ which is at a comparatively much higher stage of phagocytic activity, nucleoplasm and cytoplasm are both much paler in color. The same observation also applies to figures 9 and 10 which were taken from two consecutive sections of a second $9 \mathrm{~mm}$. pig embryo. In examining the literature bearing upon this subject it is of interest to note that similar changes in the basophilic character of the cytoplasm is described by Downey ('10) in the phagocytes of the lymphorenal tissue of the ganoid fish, Polyodon spatula, as indicated in the statement that "as seen in Polyodon these cells are strongly basophilic right after phagocytosis (fig. 2). As the phagocytosed erythrocyte breaks down the cell gradually becomes pale and often metachromatic" p. $85 .{ }^{1}$

1 Kyes ('15, p. 546) in a recent paper also describes in the liver of birds variations in nuclear structure and cytoplasmic staining reaction of endothelial cells as correlated with the intra-cellular digestion of ingested crythrocytes. 
Turning finally to the cells of the third group it will be observed that their most distinguishing characteristic is the presence of cytoplasmic vacuoles. The nuclei may be round or flattened, are usually more or less eccentric in position and do not differ materially from the nuclei of the phagocytically active macrophags. The vacuoles vary greatly in number and size, so that while in some cases only one or two may be observed, in other instances they are sufficiently numerous to fill almost the entire cell body (figs. $14 \mathrm{vcm}$. and 13). While many of these vacuoles are filled with an apparently homogeneous material which is non-staining with Giemsa, others contain remnants of hemoglobin and nuclear staining elements. In comparing such cells as figure 5 with its almost entirely digested erythrocytic inclusion, figure 6 and $14 \mathrm{pcm}$., with large vacuoles containing just a trace of ingested material, and figure $8 b$ in which one of the vacuoles contains a cellular remnant while the two others are practically clear, there can hardly be any question but that many if not the majority of these vacuoles have arisen in connection with intracellular digestive processes. Upon the complete transformation of the chromatic elements of the ingested erythrocyte there may thus still remain, for a time at least, a non-staining vacuole-like structure in the cytoplasm of the phagocyte.

In resume it appears, therefore, that the size, form, nuclear and cytoplasmic difference between these three types of cells are to be regarded as correlated with variations in the degree of differentiation and functional activity rather than as indicative of differences of a more fundamental character. The most prominent function of these cells being that of phagocytosis, they may not inadequately be designated as the coelomic macrophags of which the cells of the first type present the least differentiated and least active stages and the cells of third type end stages in functional activity. That these coelomic cells are not only manifesting normal functional changes and cytological differentiation but are also undergoing cell multiplication is positively demonstrated by the not infrequent occurrence of mitosis (figs. 3 and 7). Indeed in some instances it appears that 
the macrophags may undergo mitosis even while still retaining incompletely transformed remnants of previously ingested material in its cytoplasm (fig. 11).

\section{Evidence as to their origin from the coelomic mesothelium}

a. Certain characteristics of the mesothelium in general. Are these macrophags of the coelomic cavities cells which have migrated into these body spaces from the neighboring blood vessels or are they tissue cells which have become detached or liberated from the tissue walls surrounding these cavities where they have undergone further differentiation and assumed phagocytic and possibly other functional activities in the serous fluids? As to the first view, while no conclusive evidence of such a migration of macrophags from the blood vessels and adjacent tissues was obtained, it is to be recognized as not improbable that such cells may enter the embryonic coelom in this manner as has been maintained by Maximow to occur in the serous cavities of even the adult mammal. But the crucial question still remains as to whether this is to be regarded as the only source of the coelomic macrophags in the embryonic body cavities.

The embryonic mesothelium consists of cells which are rather flattened in form. The nuclei also have a correlated flattened oval shape and cell walls are not clearly evident. Typically these cells form a single epithelial layer lining the coelomic cavities (mes in figs. 15 to 18 and 41 to 44). Such a layer is, however, by no means always sharply defined, for in various regions the surface cells are in such an intimate syncytial association with the deeper lying cells that characteristic structural differences between them are not readily evident, indeed in certain regions the conditions are such as to suggest that the surface mesothelial cells may have given rise to many deeper lying cells comparable to the endothelial growths described by Mall ('12, pp. 258,261$)$ in certain endocardial regions of the heart. In a careful study of the mesothelium as seen in serial sections, it may be noted that the form and structure of its component cells are not always constant throughout the body cavities. In various regions the flattened mesothelial cell body, as well as 
its nucleus are observed to have assumed a more rounded form and not infrequently a more basophilic stain reaction. Instances of such changes involving only single cells or small groups of cells are especially evident in the visceral epicardium. Cells may be observed in which the nuclei instead of being oval or flattened are more rounded or spherical in shape and not infrequently indented in a kidney shaped manner (figs. 17 and 42). The cytoplasm also is rounded up, the cell as a whole projects from the mesothelial surface and in some instances is attached by only a slender basal cytoplasmic process (fig. 41). It may be observed that as a rule the cytoplasm of such cells also presents a more basophilic stain. Many of these cells have every appearance of being destined to become subsequently detached from the coelomic wall, and it appears evident that when liberated into the body cavity they would be practically indistinguishable in either nuclear or cytoplasmic structure from the macrophags already present in the serous fluid. The important point that the mesothelial cell may function in a phagocytic manner seems clearly demonstrated in figure 42 showing erythrocytic inclusions in the mesothelial cytoplasm. Figure 44 represents a section through a region of the visceral epicardium in which the proliferative activities involve a larger number of cells. Many of the apparently recently liberated cells are phagocytically active, present vacuoles and bud-like cytoplasmic processes. and appear identical with the typical coelomic macrophags.

Are we to conclude from such data that the coelomic mesothelium is really giving rise to coelomic macrophags? In view of the close approximation of many of the mesothelial cells to the macrophags in both their cytological characteristics and potential phagocytic functions, as observed with the present technique, it would not appear a great step to their differentiation into such cells. But a substantial proof of such a process is a more difficult matter especially from fixed material where all the intermediate stages in a given case cannot of course be directly observed. In evaluating the present data it seems clear, however, that the form and surface relations of the cells 
just described are at least not to be discarded as being merely misleading appearances due to tangential planes of section as can be ascertained from the serial sections. The possibility was also considered as to whether such cell forms may not be due to a shrinkage or folding of the coelomic walls or artificial ruptures of the mesothelial surface. All of these artificial conditions may of course occasionally occur in consequence of the histological technique employed but the rounded projecting cells do not have the appearance of elements artificially torn from the living mesothelium. If they are the products of histological shrinkage, it is not easy to understand how single isolated cells could be made to assume the present forms, for such cells may be found in regions of the coelomic wall where the regular surface curvature is not indicative of any artificial irregularity in its reaction to fixing agents. When found in regions where the surface of the wall appears more irregular, the cell types in question may occur on both convex areas of the slight surface elevations as well as in the concave areas of the mesothelial depressions. What appears a criticism of a more serious character, however, is the possibility that the cell forms under consideration are either instances of cells from the adjacent mesenchyma and blood vessels migrating through the mesothelium to reach the coelomic cavities or else coelomic macrophags themselves merely resting upon or in close proximity to the mesothelial surface. That a coelomic macrophag may occasionally be caught in the coagulum of the serous fluid and fixed in close contact with the coelomic surface must be granted. Furthermore since one is apparently forced to admit that erythrocytic elements, as will be subsequently described, must enter the coelom from extra coelomic regions it seems necessary to admit the possible migration of other cellular elements into the embryonic coelom. Much of the evidence also tends to be vitiated by the absence of decisive cytological differences between many of the mesothelial cells and either the coelomic macrophags or similar cells occurring in the vascular channels.

In view of the above difficulties it becomes necessary to ascertain whether there exists any other sources of evidence condu- 
cive to a more convincing conclusion regarding the problem. The results of such a further study may be presented in the form of two groups of data: the first referring to the character of certain cellular masses found free in the coelomic cavities and the second to the structure of the mesothelium in certain regions of the coelomic walls.

b. Free cell masses in the coelomic cavities. In addition to single free coelomic cells there are also found certain interesting groups or masses of cells (figs. 15 and 16). Such masses are of fairly constant occurrence. Some of them may consist of only two or three component cells (fig. 15) or of a much larger number of cells as in figure 16 which is a section of a mass extending through as many as five sections.

These masses cannot be said to represent merely a loose aggregation or agglutination of otherwise free coelomic macrophags, for upon closer study it may be observed that as a rule their component cells are organized into a definite peripheral or epithelial layer with an occasional cell more centrally situated. Consequently as seen in section, the larger masses present the appearance of epithelial rings surrounding a lighter and less cellular core. The majority of the cells in these masses, especially the more peripheral ones, are indistinguishable in both nuclear and cytoplasmic structure from the mesothelial of the adjacent coelomic walls. In other words there is every indication that these masses are groups of mesothelial cells in which the mesothelial character of the cells are still clearly evident. Upon the careful examination of serial sections it can also be definitely established that the majority of these masses (such as shown in figs. 15 and 16) are entirely free in the coelomic cavity, nor do they present the appearance of having been artificially separated from the coelomic walls. Occasionally such masses are, however, still attached to the coelomic wall and their relations in this case are such as to indicate that the mesothelium has grown out into the lumen of the coelom in the form of a papillary projection which may subsequently become detached. We have therefore, what appears to be a clear case of the actual separation of mesothelial cells from the coelomic wall and lying free in the coelomic cavity. 
The important question next arises as to the fate of these mesothelial cell masses. How long they may persist as definitely organized structures the present data does not indicate. While mitotic figures were not observed neither was there any evidence of degeneration noted. That their component cells may assume phagocytic activities is indicated in the smaller of the two masses in figure 15. But the point especially pertinent to our present purpose is the fact that some of these masses show evidence of further modification and subsequent disintegration into isolated free cells. In the smaller of the two groups shown in figure 15 the nuclei are more rounded in shape and the epithelial character of the component cells is no longer so clearly evident. The single isolated cell in the same figure is apparently of the same type except that the nucleus has assumed a kidney shape and the cytoplasm a deeper basophilic stain. These changes seem strikingly shown in figure 16 in which several of the peripheral cells have become more spherical in form and the cytoplasm takes a darker stain. Of the two approximately spherical cells in the lower part of the figure, one is partially and the other almost entirely free from the main mass. Such cells appear quite comparable to the basophilic cells or macrophags found free in the coelomic cavities.

Granting the correctness of the above conclusions, these disintegrating mesothelial cell masses, therefore, furnish a type of evidence indicative of the cytological transformation of mesothelial cells into coelomic macrophags which appears to obviate the possible objections previously noted with reference to similar changes at the surface of the coelomic wall. For it is evident that the rounded cells at the periphery of these masses can certainly not be regarded as migratory cells from mesenchymal or vascular sources and it is highly improbable that they represent free coelomic macrophags incidentally resting or fixed at the surface of the mass.

c. The mesothelium of the pleuro-pericardial and pleuro-peritoneal membranes. The second of the two sources of evidence referred to on page 84 is found in the regions concerned with the subdivision of the embryonic coelom by the development of the 
pleuro-pericardial and pleuro-peritoneal membranes. These membranes as can be directly observed, are localized centers of increased mitosis and cellular growth. Without taking into account here the deeper lying causes it appears evident that this increased cellular proliferation is an important factor in the gradual outward extension of the coelomic walls or membranes, the final fusion of the juxtaposed surfaces of which is destined to effect a closure of the pleuro-pericardial and pleuro-peritoneal canals. In such regions of fusion the free mesothelial surfaces necessarily disappear. Consequently, if mesothelial cells can differentiate into coelomic macrophags such regions might be expected to furnish valuable evidence of such a process.

Figure 43 is one of fourteen sections of such a region in a $7 \mathrm{~mm}$. pig embryo, showing the embryonic pleural cavity $(p c)$ and the pleuro-pericardial canal $(p p l c)$. At the center of the figure is seen a section through the distal border of the pleuro-pericardial membrane $(p p)$ for the left pleuro-pericardial canal (the embryo having been cut in the sagittal plane). Figure 14 shows the same central mass drawn at a higher magnification. If this cellular mass is traced back through the fourteen sections in which this membrane is present to its attachment to the parietal wall, its component cells are found to merge and become continuous with the mesothelial and mesenchymal elements at the juncture of the parieto-pleural and parieto-pericardial walls. Directing attention more especially to the present object of inquiry it is important to note that toward the more peripheral or distal margins of these advancing membranes the superficial cells have a more nearly spherical shape and that a definite flattened mesothelium is no longer evident. In the more central portion of the section shown in figure 14 there may be recognized a somewhat more definite layer of mesothelial cells (mes) surrounding a central core $(c)$. Toward the periphery of the section, however, the cells are no longer so intimately united and many of them are partly if not completely detached as free rounded cells. The structural characteristics of such an area is not indicative of degenerative changes. On the contrary the frequent mitotic figures $(m)$ furnish ample proof of active cell multiplication and 
there is abundant evidence of phagocytic activities $(p c m)$, intra cellular digestion and vacuole formation $(v \mathrm{~cm})$. It may be further observed in these regions that the more superficial cells are not only modified in form, but that the cytoplasm also tends to take a deeper basophilic stain. Such cells as $i \mathrm{~cm}$ and $p \mathrm{~cm}$ are certainly identical in structure with the coelomic macrophags. At the same time there are present all transitional stages between these cells and the original mesothelial elements. Finally beginning at these proliferating areas, detached free cells of the same type may be traced through successive sections out into the adjacent body spaces as they become scattered throughout the pericardial, pleural and peritoneal cavities where they appear indistinguishable from the free cells normally present in these regions. Evidently here again, just as in the case of the free mesothelial cell masses previously described, the proliferating and disintegrating mesothelium is giving rise to free cells functioning as macrophags in the coelomic cavities.

In resume it may be stated, therefore, that the data derived from both the pleuro-pericardial and pleuro-peritoneal membranes and the free mesothelial cell masses support in a substantial manner the conclusion suggested by the cytological conditions observed at the surface of the coelomic walls. Namely, that the coelomic mesothelium is an important source of the phagocytic cells found in the embryonic coelom, and that as these mesothelial cells round up and become detached from various regions of the coelomic wall, they assume structural and functional characteristics identical with that of the coelomic macrophags typical of these embryonic body cavities.

\section{ERYTHROCYTIC ELEMENTS IN THE COELOMIC CAVITIE\$}

As already indicated (p. 76) the second group of cellular coelomic elements are characterized by their eosin staining qualities and non-phagocytic activity. These eosin staining elements again fall into two sub-groups, the one consisting of small non-nucleated bodies and the other of larger nucleated cells. 


\section{Small eosin staining bodies}

In figures 14 and 20 several small round red bodies $(e)$ are to be observed about a third or less than a third the size of an average erythrocyte. Such bodies were found more or less constant in young pig, mouse and rabbit embryos although they may vary considerably in number in different specimens. These structures may be observed lying free anywhere in the coagulated coelomic fluid or, as is more frequently the case, in contact with the coelomic walls. As a rule they are quite round, sharply defined and take a brilliant red stain with Giemsa and Azur-eosin. Upon careful focus they sometimes present the appearance of a slightly clearer central area. They are nongranular in structure. Occasionally similar bodies are also found in the circulating blood.

As to the nature of these bodies, the first suggestion to present itself is that of cytoplasmic fragments of disintegrated erythrocytes. Upon closer examination, however, it may be observed that a narrow basophilic rim can in many cases be detected at the periphery of structures in question (figs. 21, 24 to 26). Consequently, without excluding the possibility of their partial or even entire cytoplasmic character in some instances, the latter observation necessitates the identification of the majority of these bodies as elements other than merely erythrocytic cytoplasmic fragments, as will be presently more fully discussed. A second possibility to be considered is that of their identification with cytoplasmic buds constricted off from coelomic macrophags. Downey (13 p. 42) in a description of the detachment of cytoplasmic buds from lymphocytes and large mononuclear cells in the lymph gland of the rabbit, found that these detached bodies may vary greatly in their basophilia and concluded "that after separation from the cell the irregular masses assume a spherical shape and that they gradually lose their basophilia." It was thought that possibly similar changes might account for the eosinophilic bodies in question, but no satisfactory evidence was obtained demonstrating transitional stages between such basophilic bodies and these intensely eosin- 
stained structures. Some of the bodies may be much paler than others, but the sharply defined basophilic rim which can still be observed in many cases seems to render them structurally different from the hyalin bodies derived from lymphocytes and mononuclear cells.

While the present data is consequently negative as to the derivation of these eosinophilic bodies from the cytoplasm of either erythrocytes or macrophags, it does, however, furnish evidence of a more positive character as to another conclusion concerning their origin. Concerning the basophilic material already described it appears significant to note that aside from the form of a narrow peripheral ring it may present pronounced additional accumulations in the form of either irregular masses (figs. 22, 23), one or more delicate crescentic masses (fig. 21) or small, compact and more or less centrally situated spherules (figs. 25, 26). In studying erythrocytic nuclei (p. 597) conditions are met with which are strongly suggestive with reference to the present question. Not infrequently both free and ingested erythrocytic nuclei are observed undergoing changes in which instead of becoming more or less compact in a single pyknotic body or broken up into several compact nuclear fragments the nucleus becomes lighter colored at its center and has a dark staining periphery (figs. 34 and 36). In such cases it appears that the dissolution or chemical modification of the chromatin proceeds from the center towards the periphery in such a manner that a stage may be reached in which the basophilic staining material remains as only a very thin peripheral envelope, the interior of which may take an eosin stain of such a character as to render it practically indistinguishable from the hemoglobin containing cytoplasm of an erythrocyte. Jolly ('07, p. 245) has further shown that under certain circumstances these changes may proceed to a complete tinctorial transformation of the entire chromatin content to oxychromatic staining material. The close approximation of the cytological appearance of such highly modified nuclei to that of the eosin staining bodies in the coelomic cavities appears to justify the conclusion that the latter are also of a similar character. Concerning the 
occurrence of such degenerating erythrocytic nuclei in the coelomic cavity two possible sources of origin may be noted: first, through the disintegration of the erythroblasts occurring in the coelom itself as will be presently described, and second, through the occasional passage or elimination into the coelomic cavities of the degenerating erythrocytic nuclei frequently found in various regions of the coelomic walls. The latter possibility would be in accord with the fact that these eosin staining bodies, as already noted, are frequently found in intimate contact with the surface of the coelomic walls.

\section{Nucleated erythrocytic cells}

Figure 18 illustrates the second sub-group of coelomic cellular elements. In contrast to the coelomic macrophags, these cells have an eosinophilic instead of a basophilic cytoplasm. The nucleus also may be more irregular in form, lobulated or even subdivided into two or more almost wholly if not entirely separated segments (fig. 19). The cytoplasm is frequently vacuolated. The cell as a whole may be either round or more irregular in shape with the peripheral cytoplasm presenting a fragmented appearance. In the material studied such cells were most frequently observed in rabbit embryos although they were also present in both mouse and pig embryos. They may occur as isolated elements or in groups consisting of two or three to a dozen cells.

Upon first examination the polymorphonuclear character of some of these cells is suggestive of leucocytic elements. On the other hand in no instance was there any special leucocytic granulation detected. On the contrary the cytoplasm is of a homogeneous structure and in many instances (figs. 18, 19) the staining reaction of both cytoplasm and nucleus is apparently identical with that of the typical erythrocytes in the same embryo. Concerning the origin of these cells the possibility was considered as to their representing a partial or abortive tendency toward erythrocytic differentiation on the part of the coelomic macrophags. There can be no question but that such cells as 
(a) in figures 18 and 19 present nuclear and cytoplasmic characteristics readily comparable to the erythrocytes to be found in the adjacent blood vessels, although this is by no means so clearly evident in such cells as (c), figure 18. In view of the recent observations of Haff ('14) and Bremer ('14) indicative of a participation of mesothelial cells in the origin of blood islands and blood cells it would indeed not appear so remarkable if the same cells liberated into the coelomic cavity would here be found to manifest a potentiality for erythrocytic differentiation. However, it must be admitted that no convincing evidence of such a differentiation was obtained. The irregular form and structural character of the nuclei of these cells is not typical of developing erythroblasts, the nuclei of which during the earlier phases of their differentiation are normally more or less spherical in shape (Emmel '14). No evidence of phagocytic activity as a characteristic which might justify associating these cells with the coelomic macrophags was observed, nor is the vacuolated and fragmented condition of the cytoplasm in many of these cells suggestive of progressive erythrocytic differentiation.

On the contrary the following considerations support a different conclusion. As already indicated wherever these eosin staining cells are found in groups, some of the cells in such a group can almost always be clearly identified as erythrocytic. It is equally evident that in the case of erythrocytic degeneration, the nuclei (i.e. of erythroblasts) may undergo form changes identical with those to be observed in these eosin staining cells. Such a lobulation and subdivision of erythrocytic nuclei can not infrequently be found even in the circulating blood (fig. 37 and the subsequent description on p. 100). Weidenreich ('03, p. 420) has fully described degenerative changes in which the erythrocytic nucleus becomes irregular in form, indented, bilobed, dumb-bell and clover leafed shaped, and finally constricted into two or more parts connected by a small thread-like strand or entirely separated from each other and thus give rise to a socalled double nucleated cell. In some cases such degenerating nuclei may become smaller, more compact and take a much darker stain, in other instances, however, the nucleus may main- 
tain a comparatively open chromatin network, as is well shown in figure 33 of Maximow's ('09) work. Such modified nuclei are indistinguishable from the irregularly lobulated nuclei of the eosin staining cells in the coelomic cavity. In other words on the basis of the present data the cells in question are evidently correctly interpreted as degenerating nucleated erythrocytes, in which the nuclei are greatly changed in form, the cytoplasm having become deficient in hemoglobin, stains a paler color with eosin and presents the vacuolated condition described by Minot ('12, p. 511) as preliminary to further changes in certain types of erythrocytic disintegration. Here and there fragments of such disintegrated cells can be readily found. Occasionally a cell is observed with a striking peripheral fringe of eosin staining material. In some cases this material has the appearance of fragments of disintegrated cells incidentally resting against or adhering to the cell in question. In other instances the union with the cell body is so complete that a question arises whether it may not represent a phase in the degeneration of the hemoglobin containing cytoplasm of the erythroblast (fig. 12).

How these degenerating erythrocytes come to be situated in the coelomic cavities is more difficult to determine. That cells with erythrocytic characteristics are normally present constantly in the embryonic serous cavities appears positively demonstrated by the character of the cellular inclusions in the macrophags. In the absence of conclusive data as to their differentiation in situ there remains the alternative assumption that under various conditions they may escape from the blood vessels and pass through the coelomic mesothelium into the coelom. Very young erythroblasts may possibly do this by an active migration although evidence of such a migration was not obtained. It may be noted that erythroblasts may also be found within such extra vascular spaces as the lumen of the Wolffian tubules; occasionally in the lumen of the developing lung buds, and in mesenchymal spaces (p. 603) throughout the embryo. 


\section{ERYTHROCYTIC DISINTEGRATION IN THE.MESENCHYMA}

1. Degenerative changes in erythrocytic nuclei with reference to:

a. The question of the mesenchymal secretion of erythrocytic elements. The fact that degenerating erythroblasts, especially their nuclei, may undergo changes resulting in the production of small red spheres or masses with either central or peripheral accumulations or remnants of basophilic material as observed in the coelomic cavities, merits further consideration with reference: first, to the bodies interpreted by Maximow as mesenchymal secretions, and second, to the ring bodies of Cabot.

Concerning the possible relation of these eosin bodies to mesenchymal activities it may be noted that Maximow ('09, p. 513) describes the observation in the blood of the embryonic rabbit of apparently similar eosin-basophilic-droplets which he states soon disintegrate in the circulating plasma. Maximow inclines to the conclusion that these bodies are secretion products of mesenchymal cells and represent an abortive or precocoius differentiation of erythrocytic or hemoglobin containing elements. Evidence is advanced for the occurrence of such a secretion in various regions of the mesenchyma, such as that of septum transversum, in the head region and adjacent to the distal ends of growing blood vessels. In these regions he records the observation of many large and small red and blue stained spherical or angular bodies generally embedded in clear vacuoles in mesenchymal cells. These bodies are described as consisting of red spheres containing one or more central blue spherules, red bodies furnished with one or more deep blue peripheral crescents or caps, or blue rings filled with a clear eosin stained content (p. 500). After the consideration of several possibilities as to their origin it is decided that they are probably elaborated in situ in the mesenchymal cytoplasm and it is stated that one can observe how the inclusion in the cytoplasm of the mesenchymal cell develops from a few initial small erythrocytic granules and how it grows in size, and the basophilic substance appears within it or on its surface. 
Since these structures are so closely similar to the small eosinophilic elements occurring in the coelomic cavities it became necessary to reexamine the evidence for an intra-cellular origin of such bodies. For the writer the subject had also an additional interest in consequence of a previous study of the cytological differentiation of erythrocytes in which there was occasion to consider the possible origin of erythrocytic or hemoglobin containing elements in the cytoplasm of the mesenchymal cell (Emmel '14).

As already indicated, the preceding results of the present investigation with reference to the eosinophilic bodies in the coelom were negative as to their origin as intra-cellular secretions. Furthermore after careful study I have been unable on the following grounds to convince myself that the bodies described by Maximow in the mesenchyma necessarily represent intracellular secretions of mesenchymal cells. In the first place these eosin staining bodies are found equally as abundant and indeed frequently even more so within the ectodermal tissue of the brain wall (fig. 33e) cranial and spinal ganglia (fig. 28) and the entoderm of the growing lung buds and digestive tube, in situations where they would be least expected if they are derivatives of mesenchymal cells. They also occur in inter- as well as intracellular situations.

Figure 31 is from the mesenchyma in the ventral thoracic wall of a $9 \mathrm{~mm}$. pig embryo and figure 32 from the mesenchyma of the septum transversum of a $7 \mathrm{~mm}$. pig embryo. It will be observed that in both cases practically all the eosinophilic bodies in question are clearly situated in inter-cellular mesenchymal spaces. Similar relations can also be readily demonstrated in the brain wall and the cerebrospinal nerve ganglia (fig. 28). On the other hand similar bodies can also be found which appear unquestionably situated within the cytoplasm of cells in the mesenchyma. Since these bodies are both interand intra-cellular in position it seems clear from this aspect of the subject that they may be as adequately interpreted as either extra-cellular elements, some of which may have become phag- 
ocytically ingested, or originally intra-cellular elements, some of which had been subsequently extruded from the parent cell.

The point then to be established is the correctness of one or the other of these two alternatives. The abundant occurrence of these elements in such tissues as the brain wall and nerve ganglia which are relatively deficient in mesenchymal cells is a fact in itself sufficient to raise a question as to their intra-cellular origin. Again upon examining the bodies in question it will be observed that they may present a variety of structural forms, among which may be noted single small basophilic spherules surrounded by just a trace of eosin staining material (fig. 31a), several basophilic spherules situated in a larger red staining body (fig. 31b), a crescent, or less frequently, a spherule of basophilic substance peripherally located (figs. 31, $c$, and $d$ and 32), or a peripheral basophilic ring completely surrounding the red stained material (figs. 31e, 33e, and 28). Now if one turns to the circulating blood of these same embryos, degenerating nucleated erythrocytes are occasionally found, as is well known, in which the disintegrating nuclei have become broken up into several small more or less rounded fragments. Again in other instances such degenerating nuclei, especially in the mouse embryo, present the appearance of a red stained central area surrounded by a peripheral basophilic ring as shown in figures $34 a$, 35 and 36 . It may also be observed in the same figures that portions of these rings may be very thin while other areas are much thicker and present the form of basophilic crescents. Similar degenerating nuclear changes can also be demonstrated in phagocytically ingested erythrocytic nuclei as partially shown in figures 4,6 and $8 b$. Now it is well known and can be readily verified that erythrocytes not infrequently escape from the blood vessels and become isolated in the mesenchymal and other tissue spaces of the embryo where they may undergo various types of disintegration (Minot, '12, p. 509). From the data derived from the erythrocytes occasionally degenerating in the circulating blood it becomes evident that these degenerating corpuscles may assume structural appearances identical in char- 
acter with the bodies under consideration. Perhaps the most constant difference between the bodies in the tissue spaces and the degenerating corpuscles in the vascular channels is the presence of only a small amount or frequently the entire absence of any cytoplasm peripheral to the basophilic rings or spherules in the case of the tissue spaces as compared with the conditions in the degenerating corpuscles of the blood. But this appears readily accounted for on the basis of a more rapid and earlier disappearance of the peripheral cytoplasm of the erythrocytes degenerating in the environment of the inter-cellular fluids. Indeed evidence of such peripheral cytoplasmic changes may be encountered even in the vascular channels as illustrated in figure 36 from a $9 \mathrm{~mm}$. pig embryo in which one of the erythrocytes shown contains only a relatively narrow rim of cytoplasm peripheral to the nuclear ring, whereas it is entirely absent in the remaining two cells. In figure $34 a$ the peripheral cytoplasm of the degenerating erythrocyte is much paler than that of the adjacent normal corpuscle. Instances in the circulating corpuscles of nuclear rings without any evident peripheral cytoplasm is demonstrated in figure 29 from the heart blood of a $7 \mathrm{~mm}$. pig embryo. It appears evident, therefore, that in pig, rabbit and mouse embryos all transitional stages can be found between degenerating nucleated erythrocytes and the eosin staining bodies in the embryonic tissue spaces.

A further possible source of origin of many of these bodies which may be noted, especially in older embryos in which nonnucleated erythrocytes are beginning to appear, is in connection with the formation of non-nucleated erythrocytes. In a previous study of the pig embryo (Emmel '14) evidence was advanced indicating the origin of non-nucleated red blood corpuscles by a process of cytoplasmic constriction resulting in the separation of the original erythroblast into a non-nucleated remainder consisting of the erythrocytic nucleus together, not infrequently, with a small amount of cytoplasm remaining from the parent cell. This nucleated remainder may present an appearance practically identical with that of many of the eosinophilic bodies under discussion. 
On the basis therefore, of their distribution, structure and close correspondence cytologically to both disintegrating erythrocytes as observed in the circulating blood, inter-cellular tissue spaces and phagocytic inclusions and to erythrocytic nuclei persisting after the formation of non-nucleated erythrocytes, the conclusion is drawn that the small eosin staining bodies in the embryonic mesenchyma are correctly interpreted as consisting primarily of disintegrating, and in many cases phagocytically ingested erythroblasts which have escaped into the embryonic tissue spaces and second, especially in older embryos, of nucleated erythrocytic bodies resulting from the cytogenetic processes involved in the formation of erythro-plastids, rather than the products of secretory or other cytological activities in mesenchymal cells.

b. Cabot's rings. The second phase of the present subject is concerned with the question of Cabot's rings. The erythrocytic ring-like structures, first observed by Cabot ('03) in anemic blood and which are now known to also occur under other abnormal conditions such as obtain in leukaemia and lead poisoning, are usually described as staining red or reddish violet with Giesma. Both Cabot (p. 455) and Naegeli ('12, p. 152), however, also record the occurrence of blue stained rings. These rings which have been interpreted as nuclear elements, possibly in part nuclear membranes, (S.chliep, '07, p. 455) are regarded as occurring only in the pathological blood of the adult organism and never in either the human or mammalian embryo (Naegeli, p. 152, Grüner, '13, p. 83). But in view of the present data it may be questioned whether analogous structures are not, however, also encountered in the embryo as well as in the adult. The nuclear rings already described in the ingested erythroblasts of the coelomic macrophags, the basophilic periphery of some of the eosin bodies in the coelomic cavity (figs. 21 to 26), the nuclear ring-like structures arising in the degenerating erythroblasts in the mesenchymal (figs. 27 and 31e) and other tissue spaces (figs. 29, 30, 34 to 36), appear closely related if not identical with the ring bodies of Cabot. In the embryo these nuclear rings, especially in the mesenchyma are typically blue 
with Giesma's stain in contrast to the reddish tone of the rings in pathological blood of the adult, although as already noted blue rings are not entirely lacking even in the latter case. This may be in part due to the different conditions under which they are formed for it is to be observed that in certain regions such as that of the brain wall and nerve ganglia many of the ring bodies stain a reddish rather than a blue tone (figs. 28 and $33 e$ ). In the embryo these rings are more frequently found without any surrounding peripheral cytoplasm, that they may, however, also occur within the still intact erythrocyte is well illustrated in figures 34,35 and 36 (also p. 96). This may be due in part to an earlier disintegration of the cytoplasm in relation to the nucleus in the case of the embryo as contrasted with the adult. Although it is not to be overlooked that Gabriel ('08, p. 604) records the observation even in the adult of ring bodies a parently lacking a peripheral rim of cytoplasm. As to the normal or abnormal character of these structures there appears no doubt but that in the embryo just as in the adult (Naegeli) their production is a phenomena of abnormal nuclear disintegration and not a normal mode of erythrocytic cytomorphosis. Concerning the conditions under which the degenerating erythrocytic nucleus will present the form of a ring or that of small compact spherules, the possibility is suggested that this may be associated in part at least with the stage of cytomorphosis at which the degenerative processes are initiated. In the younger erythroblasts, as is well known, the nucleus is both relatively larger and the chromatin granules are more loosely distributed throughout the nucleoplasm, whereas in later stages of differentiation the nuclei become not only smaller but also much denser and more compact in chromatin structure. Degenerative changes initiated at these different stages may consequently be expected to manifest correlated differences in nuclear disintegration. It is possible that a longer persistence of the thickened reticulum described by Cupp ('15) at the periphery of the erythrocytic nucleus may also be associated in part with the formation of nuclear rings. 


\section{Degenerating erythroblasts and the so-called eosinophilic leucocytes in embryonic mesenchyma}

Attention has already been directed to the fact that upon first impression certain characteristics of the eosin staining coelomic cells were suggestive of leucocytic elements but that the results of subsequent investigation indicated the nature of these cells to be that of degenerating erythrocytes. In the case of the rabbit eosinophilic leucocytes are also absent in the serous cavities of the adult (Weidenreich, '12, p. 127). In connection with this conclusion it is to be taken into account, however, that cells which appear practically identical in both nuclear and cytoplasmic structure with these degenerating erythrocytes in the coelomic cavities are also found in the intercellular spaces of the mesenchyma of the same embryos (figs. 38 to 40), concerning the nature of which Maximow ('09) in his description of the $7 \mathrm{~mm}$. cat embryo reaches the theoretically important conclusion that they are eosinophilic leucocytes differentiating in situ from mesenchymal cells.

The apparent identity of these cellular elements of the mesenchyma, both as described by Maximow and as observed in the present material, with the cells interpreted as degenerating erythrocytes in the coelomic cavities has rendered it necessary to reexamine the evidence concerning the nature of the cellular structures in the mesencyhma. In presenting the results of such a study it may be stated that the following considerations have led to a negative conclusion as to the leucocytic character of the cellular elements in question in the mesenchyma. In the first instance it is to be observed that no special eosinophilic granulation can be demonstrated in these cells (figs. 38 to 40). Indeed Maximow himself, although maintaining that in the mesenchymal wandering cell the nucleus becomes lobulated into a number of subdivisions held together in some cases by only fine connecting strands, is nevertheless obliged to admit that no leucocytic granules can be recognized in the cytoplasm of the cells here in question (p. 525). In explanation of this, Maximow points out that it is likewise also very difficult to demon- 
strate such granules in the granular leucocytes of even the adult cat and that consequently failure to demonstrate these granules in the embryonic cells does not constitute evidence of a necessarily negative character. With reference to this point, however, it may be noted that the eosinophilic, non-granular cells in question are not limited to the embryo of the cat for apparently the same cells can be also demonstrated in the embryonic mesenchyma of the rabbit, mouse and pig, mammals in the adults of which a corresponding difficulty in staining the granules in the granular leucocytes cannot be said to be encountered. Second it can be demonstrated that degenerating erythroblasts, occasionally found in the embryonic circulation may undergo cytological changes apparently identical with the structural characteristics to be found in the mesenchymal cells in question. Erythrocytic nuclei as is well known, may become very irregular in shape: bilobed or even constricted into several subdivisions. Early stages in such nuclear changes are indicated in figure 37 and reference has already been made to Weidenreich's account on this subject (p. 595). In man lobulation of erythrocytic nuclei has also been described under pathological conditions in the circulation of the adult (Jünger, '00, p. 109). Maximow ('09, p. 478) also recognizes the occurrence of such nuclear lobulation even in the embryonic circulation but described the nuclei in such instances as becoming smaller, more compact and taking a darker stain. It may be questioned, however, whether this is necessarily always the case. For even in the circulating blood, degenerating erythroblasts may be observed with lobulated nuclei which cannot be said to present an especially more compact structure (fig. 37). A similar comparison can be made in figure 33 of Maximow's work in which lobulated erythrocytic nuclei are shown which do not appear either essentially darker in stain nor more compact in structure than the unchanged nuclei of the adjacent erythroblasts or the nuclei of the co-called leucocytes in figure 27 of his monograph. As for the relative size of the cells no conclusive distinction can be clearly drawn on this basis between the cells in question in the mesenchyma 
and the erythroblasts in the circulating blood (cf. figs. 37 and 38 , drawn with the same magnification).

That the cytoplasm of the degenerating erythrocyte may become vacuolated and assume a lighter stain is illustrated in figures $37 d$ and $34 a$. Similar degenerative erythrocytic changes have also been described by Minot ('12) and may be observed in tissue cultures (Emmel '14). Finally, attention has already been directed to the fact that erythrocytes frequently escape from the vascular channels into the adjacent embryonic tissue spaces where they may eventually disintegrate, be ingested by phagocytes, or possibly in some cases eliminated through the lymphatic vessels as suggested by Minot ('12) for mammals and as observed by Clark ('09) in the living tadpole. Cells which can be unquestionably identified as such degenerating erythrocytes can be readily observed in the mesenchyma. The nuclei may vary from round to highly irregular and lobulated forms and the cytoplasm may be paler in stain reaction, vaculoated and under certain conditions may even disappear. Among these cells are such forms as are illustrated in figure 40 the nucleus of which may still be identified as erythrocytic as seems clearly indicated by the persistence of a thickened peripheral accumulation of chromatin in a manner comparable to that of the circulatory erythrocytes shown in figures 37 and 34 . Such a nuclear structure is in decided contrast to that of the adjacent mesenchymal cells as may be seen in the same figures. Practically all transitional stages can be found between such cells and those shown in figure 38 representative of the so-called eosinophilic leucocytes under discussion. It appears evident that such partial hemolysis, cytoplasmic vacuolation and consequent peripheral disintegration in the erythrocytes which have escaped into the mesenchyma may result in the production of cytoplasmic processes of such a character as not to be readily distinguishable from cellular processes of the adjacent mesenchymal cells with which they appear to fuse. Such cells may present the deceptive appearance of differentiation in situ from mesenchymal cells as indicated in figures 39 and 40 . 
In conclusion, therefore it may be stated that in view of the fact that the cellular elements under consideration in the mesenchyma are not only deficient in any definite leucocytic granules but that nucleated erythrocytes degenerating in the embryonic tissue spaces may assume cytological characteristics apparently identical with those of the non-granular eosin staining cells with lobulated nuclei in the mesenchyma, it appears difficult to escape the conclusion that many if not the majority of the latter just as in the case of the coelomic elements, are degenerating erythroblasts rather than granular leucocytes developing in situ from mesenchymal cells.

Concerning the distribution of such degenerating erythroblasts in the embryonic tissues, it is of interest to note that the corpuscles in which the nuclei assume the lobulated condition without becoming noticeably more compact in structure or darker in staining reaction occur typically in the looser tissues with larger intercellular spaces. On the other hand degenerating erythroblasts assuming the more compact forms containing either nuclear rings or dark homogenous nuclear spherules, as previously described, and presenting a great reduction if not entire absence of peripheral cytoplasm occur typically in the denser tissue regions (cf. figs. 39 and 40 with $31-33$ ). Presumably the structural characteristics which may be presented by the degenerating erythroblasts are in part determined by the nature of the environment in which such degeneration takes place (cf. however also p. 98).

In concluding the present subject it may be stated with reference to Maximow's most interesting and stimulating work concerning the participation of the mesenchyma in the formation of blood cells, that while the present results do not in themselves necessarily constitute a conclusive argument against such a possible role of the mesenchyma, they are presented as contributing toward an evaluation of some of the evidence which has been advanced toward the establishment of such a conclusion. 
VI. CONCERNING THE PRESENT STATUS OF THE QUESTION AS TO

THE ORIGIN OF MACROPHAGS FROM THE COELOMIC MESOTHELIUM

\section{Embryological and comparative}

As already intimated, a study of the cellular elements in the embryonic coelom of mammals has not been previously made. At the same time it may be observed that the present conclusion that the coelomic epithelium may give rise to free functional elements in the coelomic cavities is indirectly supported in an interesting manner by the results of a number of recent investigations. Reference may be made to Bremer's ('14) work in which he finds anlages of the earliest blood vessels in man to arise from the surface mesothelium. His "observations point to the ingrowths of the mesothelial layer covering the yolk-sac and body-sac as the anlages of the blood vessel endothelium and of a lesser extent of the blood corpuscles" (p. 459), and the conclusion is drawn that "True blood islands may occasionally arise by the multiplication of the cells of the mesothelial ingrowths, or scattered blood corpuscles may arise singly within these ingrowths" (p. 464). For the cat embryo Schulte ('14) records the occurrence of "funnel-like diverticuli of the coelom, the walls of which are intimately united to the blood vessels," and which he suggests may be of morphological significance with reference to the development of the embryonic blood vessels (p. 80). Haff ('14, pp. 346 and 333) states the conclusion that the peritoneum covering the embryonic liver of the chick may give rise to cells within the liver differentiating into erythrocytes. Scammon ('15), in the histogenesis of the Selachian liver, records the occurrence of mesothelial tubules "the walls of which are continuous with the splanchnic mesothelium and the lumen with the coelomic cavity" (p. 276). Although unable to find that the lumen of these tubules connected with that of the blood spaces, it is stated that the tubules break up into mesenchymal strands and that "the mesenchymal and endothelial cells form free anastomosis" (p. 280). Phylogenetically reference may also be made to primitive vascular conditions in 
some of the lower invertebrates. Lang ('04, p. 152) states that in the body cavities of annelids there occur not only sex cells but also amoebocytes (lymphocytes) and coelomocytes, some of which as the result of formation of hemoglobin are designated haemocytes, and that these elements arise from the coelomic epithelium. Abbot ('13, p. 6) describes the observation of hemoglobin containing cells or 'haematids' in the body cavity of the Echiurid worm, Thallasema mellita, arising from the "living membranes of the general body cavity which buds off masses of cells, usually eight to twenty-four in number, which ultimately break up into individual haematids" (p. 6). Data of a similar character could be greatly extended not only among annelids, but also in the Echinoderms and Coelenterates. The views of Bütschli ('83), His ('00) and Arnold ('04) concerning the phylogenetic origin of the circulatory system from the body cavities are well known.

\section{In adult mammals}

In connection with these embryological results the question arises as to whether these mesothelial activities are confined to the embryo, or whether such a potentiality may be retained even in the adult animal. Without entering into a detailed account of the extensive hematological literature bearing upon the much debated question as to the nature and origin of the free cells in the adult serous cavities (for a discussion of which cf. Weidenreich ('11, pp. 126-138), certain aspects of the problem may briefly be considered in the light of the more recent investigations.

Schott ('09), from cytological and experimental studies reaches the important conclusion that the surface lining cells of the adult body cavities in the guinea pig and rabbit are not highly specialized and fixed passive structures, without potentiality for further differentiation, but that on the contrary they may assume phagocytic activities, become detached from the serous membrane and be liberated as free, active, living cells identical with the lymphocytes and macrophags of these cavities. He states: 
"Wir müssen aber andrerseits auf Grund unserer Flächenpräparate vom Netz . . . . unbedingt an der Fähigkeit der Deckzellen sowohl zur aktiven Phagozytose wie zur Isolierung und Loslösung aus dem Zellverbande festhalten" (201), and in conclusion finds: "dass die grossen ungranulierten Exudatzellen und nicht nur diese, sondern auch die grossen Elemente des normalen Transudates, Abkömmlinge fixer oder sessiler Gewebsbestandteile sind. Ursprünglich fixe Gewebselemente lösen sich aus dem Zellverbande, runden sich ab und werden zur freien Zellen der serösen Höhlen" (p. 208). Among subsequent investigators confirming this conclusion may be noted Szecsi ('12) who states: "Aus der Endothelzellen wird zuerst durch Wachstum im Plasmaabrunding der Lymphoidozyte und Macrophage" (p. 18). This is again reaffirmed in the later work of Szecsi and Ewald ('13, p. 182). Lippman and Plesch ('13) in a summary of their Thorium experiments, relative to the exudate cells of the serous cavities further support this conclusion: "Somit können die 'kleinen lymphozyten' weder Hämatogen sein (aleukozytäres Blut.'), noch von den Adventitialzellen, noch von den taches laiteuses stammen-sie sind Abkömmlinge des serosaendothels" (p. 1396). Weidenreich ('11) writes with no uncertainty concerning the origin of the large phagocytic cells of the serous cavities: "sie sind losgelöste Netzelemente, und somit sowohl Abkömmlinge von Deckzellen als auch Bindegewebszellen, . . . . die nicht degenerieren, sondern in Gegenteil sehr lebenskräftig und mitotischer Teilung fähig sind" (p. 133). In opposition to the above conclusion Pappenheim-Fukushi ('13) maintain that the exudate cells of the serous cavities are not mesothelial derivatives: "Sie sind Abkömmlinge nicht der Deckzellen" (p. 305). . . . . Allerdings leiten Lippman und Plesch die entzündungezellen ebenso wie Wiedenreich-Schott, auch von den serosen noch nicht angenommen werden darf" (p. 289). Recently through the employment of vital staining methods new evidence has been introduced into the discussion of the problem. Thus Goldman ('12), on the basis of his studies with vital stains, draws a distinction between the macrophags and serous mesothelium on the ground that the 
latter in contrast to the former does not stain with pyrolblue (p. 45, 49) and the inference consequently arises that the macrophags of the serous cavities are not derived from the mesothelium. Tschaschin ('13, p. 350) not having succeeded in obtaining a vital stain for the peritoneal endothelium, also draws a similar conclusion. In experiments with celloidin plates inserted into the peritoneal eavity, Tschaschin ('13) furthermore failed to find that the mesothelial cells manifested any special reaction or potentiality for transformation, but that on the contrary they quickly disquamated and under the conditions of the experiments took no part in the formation of macrophags (pp. 271, 285, 289).

Unanimity cannot, therefore, be said to have as yet been attained in the solution of the problem. As already indicated with reference to negative evidence, perhaps the strongest data which has been more recently advanced is that derived from such results as that of Goldmann and Tschaschin with vital stains. It remains to be seen what is to be the final evaluation of the data derived from this method. At the present stage of such investigations it may not be without value to note the following points which do not appear to render some of the results so far attained as of a necessarily conclusive character with reference to the question in hand.

It may be observed that if the reaction of the given tissue (whether endothelial or mesothelial) to the vital stain is negative and that of the macrophags positive, it appears, in some cases at least, that this is taken as evidence that the macrophags could not be derivatives of the tissue in question. But with reference to such a conclusion the question arises as to whether it has been clearly demonstrated, first, that there is such a sharp difference in the reaction of the mesothelium and macrophags and second, that even a material difference in vital stain reaction in itself establishes an entire absence of any genetic relalationship between the tissues under consideration. In the first place it is not to be overlooked that in some instances at least both mesothelium and macrophags may react alike, for Schulemann ('12) after injection of Trypanblue in rabbits did not ob- 
tain a stain reaction for either the macrophags of the peritoneal cavity or the peritoneal epithelium, a result which, as he himself notes (p. 239) consequently substantiates Schott's conclusion. On the other hand it has been shown that in cases where the macrophags do manifest a typical vital stain reaction the reaction of the mesothelium is by no means necessarily entirely negative, for Evans ('14) records the observation that whenever certain cells such as the clasmatocytes (resting wandering cells) of the connective tissues and macrophags of the great serous cavities "react in a typical intense manner to the vital stairf" other cells "are normally found with much smaller often very minute granules of the stain" in which latter class, it is important to observe, is included the mesothelium "lining the peritoneum and covering its organs" (p. 100). Again it does not appear that the fact that the reaction of a tissue to the vital stain in a given case is negative or stains only slightly in contrast to the macrophags necessarily leads to the conclusion that such a tissue cannot give rise to the macrophag elements. A case in point is that of the endothelium of some of the larger blood vessels in the liver. It has been shown for example by Taschaschin ('13) that whereas after 'Kallargol' injection black silver granules are specifically deposited in the large mononuclear elements or macrophags of the blood, they are not found in the endothelial cells of the portal vessels (p. 353). On the other hand Batchelor ('14), while he finds that injections of trypan blue just as in the cașe of 'Kallorgol' , do not normally stain the endothelium of the larger portal vessel of the liver in contrast to the positive reaction of some of the phagocytic endothelial giant cells in the same organ, nevertheless endothelial proliferations experimentally produced in the same vessels by means of albumen emboli do react to the stain: thus newly formed endothelial tissue at the site of the embolus and in its immediate neighborhood it is stated, "is stained vitally, a phenomenon never seen with the normal endothelial cells of larger vessels, and showing that the vital stain is adequate for the detection of endothelial growths although the parent tissue does not show this property" (p. 139). MacCurdy and Evans ('12, p. 1695- and 
also Tschaschin ('13, p. 370), record the observation that in the case of blood vessels in the vicinity of wounds or other irritants, the vascular endothelium which normally does not stain, may under these changed conditions now react to vital stain. Finally it may be noted that the macrophags themselves do not all react alike. Thus Tschaschin ('13b) recognizes the occurrence of distinct variations in the intensity of the vital stain in the macrophags: "Es muss jedoch hervorgehoben werden, dass die freien Macrophagen der Bauchböhle sich vital bei weitem nicht immer gleich intensiv färben" (p. 351). Tschaschin associates this with variations in different types of stain and methods of injection, rather than as furnishing any ground for identifying these lighter stained cells with detached cells from the peritoneal endothelium, but in view of the above referred to results by MacCurdy, Evans and Batchlor, it does not appear that the latter possibility can as yet be said to have been successfully eliminated. Variations in the vital stain of such detached cells may well be correlated with different degrees of differentiation as has indeed been emphasized even by Tschaschin (p. 382) in connection with difference in the vital stain reaction of blood cells so that undifferentiated cells reacting negatively with a given vital stain may with further differentiation give a positive reaction with the same stain. Consequently on the basis of the data so far at hand, the ground does not appear clear on which it can be stated with entire assurance that the mesothelial cells which are able to take up a small number of the granules of the vital stain, may not under given conditions just as in the case of the vascular endothelium, come to manifest an increased expression of the same function such that as detached cells would identify them with true macrophags. ${ }^{2}$

In conclusion, therefore, it appears that a convincing case can hardly as yet be said to have been made against the possible per-

\footnotetext{
2 In connection with the question as to the degree to which mesothelial and endothelial tissue may manifest common morphological and functional potentailities it is of interest to note the results of Hooper and Whipple ('15) indicating that mesothelium as well as endothelium may participate in the formation of bile pigments.
} 
sistence in the adult mammal of the potentiality on the part of the mesothelium of contributing, under certain stimulating environmental conditions, liberated cellular elements to the body cavities in a manner comparable to the processes taking place in the embryonic coelom.

\section{RÉSUMÉ}

1. A considerable number of free cellular elements were found to be more or less constantly present in the coelomic cavities of pig, rabbit and mouse embryos.

2. These coelomic elements may be described as falling into two groups, the one consisting of basophilic staining and usually phagocytically active cells and the other of cellular elements characterized by their eosinophilic staining qualities and nonphagocytic activity.

3. The coelomic macrophags

a. The basophilic cells may be conveniently further subdivided into the following types: 1) cells relatively smaller and more spherical in form, containing an occasional small cytoplasmic vacuole and a rather dark staining, round or kidney shaped nucleus; 2) cells usually larger in size, more oval or irregular in form, containing one or more phagocytic inclusions, having a round or kidney shaped and more or less eccentrically situated nucleus and the cytoplasm and nucleoplasm of which take a considerably lighter basophilic stain; 3) cells characterized by the vaculoated condition of the cytoplasm and the not infrequent occurrence of cytoplasmic processes or buds projecting from the surface of the cell.

$b$. The transitional stages which may be found between these different cells are of such a character as to justify correlating their size, form, nuclear, and cytoplasmic differences with variations in differentiation and function. Consequently practically all of these cells are here regarded as belonging to a common group which in view of their evident phagocytic functions may be designated as coelomic macrophags.

c. As to the origin of these coelomic macrophags, some of them may no doubt have entered the coelomic cavities from 
extra coelomic regions, but the present results do not indicate this to be the only source of origin of these cells. On the contrary the observation that at the surface of the coelomic walls, in the free mesothelial cell masses, and the pleuro-pericardial and pleuro-peritoneal membranes, mesothelial cells are found which are rounded in form, manifest phagocytic characteristicis apparently identical with that of the typical macrophags, and the evidence advanced that these cells may become detached as free cells, support the conclusion that the coelomic mesothelium is an important source of origin for the phagocytic cells found in the embryonic coelom.

4. Erythrocytic elements in the coelomic cavities.

a. The second of the two groups of coelomic cellular elements above indicated again fall into two sub-groups, the one consisting of small non-nucleated bodies and the other of larger nucleated cells.

$b$. The present data indicate these structures to be erythrocytic in nature; the larger nucleated cells representing degenerating nucleated red blood corpuscles and the smaller eosin staining bodies consisting chiefly of degenerating erythrocytic nuclei.

5. Erythrocytic disintegration in the mesenchyma.

a. In the embryonic mesenchyma there occur small eosin staining bodies which have been interpreted as hemoglobin containing secretion products of mesenchymal cells (Maximow). But on the basis of the present evidence concerning their distribution, structure and close cytological correspondence to disintegrating erythrocytes as observed in the circulating blood, intercellular tissue spaces and phagocytic inclusions and to erythrocytic nuclei persisting after the formation of non-nucleated erythrocytes, the conclusion is drawn that the bodies in question represent chiefly erythrocytic elements consisting of degenerating and in many cases phagocytically ingested erythroblasts and, in older embryos, including nucleated erythrocytic bodies arising in connection with the formation of erythro-plastids or non-nucleated erythrocytes, rather than the products of mesenchymal secretory activities. 
b. The ring-like configuration presented by many of these degenerating erythrocytic nuclei appear identical in many respects with the nuclear structures occurring in the erythrocytes of pathological blood known as Cabot's rings and they consequently furnish evidence that the latter are not limited to the blood of the adult animal as has been previously assumed (Naegeli).

c. Certain cellular elements in the mesenchyma present in some respects the appearance of eosinophilic leucocytes and are suggestive of a possible mesenchymal origin as maintained by Maximow. In view of the fact, however, that all of these are deficient in any definite leucocytic granules and that nucleated red blood corpuscles escape into the embryonic tissue spaces where they may present degenerative nuclear and cytoplasmic characteristics apparently identical with those of the non-granular eosin staining cells in the mesenchyma, it appears difficult to escape the conclusion that the majority of the latter, just as in the case of the corresponding coelomic elements, are degenerating erythrocytes rather than granular leucocytes developing in situ from mesenchymal cells.

6. Concerning the problem of mesothelial origin of macrophags.

a. In connection with present conclusion that the coelomic epithelium may give rise to free functional elements in the coelomic cavities, it appears not without significance on embryological and comparative grounds to note the recent work of Bremer, Haff and Schulte concerning the participation of coelomic epithelium in vasculogenesis and the formation of blood corpuscles in vertebrate embryos and the conditions in certain invertebrates where the coelomic epithelium gives rise to cellular elements functioning as respiratory and phagocytic cells in the body cavities (Lang, His, Arnold).

$b$. Regarding the origin of the macrophags in the serous cavities of adult mammals unanimity still remains to be attained in the solution of the problem. On the basis of the data so far at hand, it does not appear, however, that a convincing case has as yet been made against the possible persistence of a potential- 
ity in the mesothelium of the adult organism of contributing under certain conditions free cell elements to the body cavities in a manner comparable to the process here described as taking place in the embryonic coelom. 


\section{LITERATURE CITED}

Аввотт, F. J. 1913 The blood cells of Thallasema Mellita. Washington University Studies, vol. I, Part I, p. 1.

Batschelor, R. P. 1914 Demonstration of preparations showing the behavior of endothelium after the introduction of emboli in the portal vein. Anat. Rec., vol. 8, p. 149.

Bremer, J. I. 1914 The earliest blood vessels in man. Am. Jour. Anat., vol. 16, p. 447.

Bü TsCHLI, O. 1883 Uber eine Hypothese bezüglich der phylogenetischen Herleitung des Blutgefässapparates eines Theils der Metozöen. Morph. Jahrb., Bd. 8, p. 474.

CABot, R. C. 1903 Ring bodies (nuclear remnants?) in anemic blood. Journ. Med. Research, vol. 9, p. 15.

Clark, E. R. 1909 Observations on living, growing lymphaties in the tail of the frog larva. Anat. Rec., vol. 3.

Cupp, C. D. 1915 On the structure of the erythrocyte. Anat. Rec., vol. 9, p. 259.

Downey, H. 1910 Phagocytosis of erythrocytes in the lymphorenal tissue of Ployodon spatula. Folio Haematologica, Bd. 9, p. 81, Archiv.

1913 The origin of blood platelets. Folia Haematologica Bd. 15. p. 25, Archiv.

Downey AND WEIDENREICH, R. 1912 Über die Bildung der Lymphozyten im Lymphdrusen und Milz. Arehiv. f. Mikr. Anat., Bd. 80, Heft. 2.

Emmes; V. E. 1914 Concerning certain cytological characteristies of the erythroblasts in the pig embryo, and the origin of non-nucleated erythrocytes by a process of cytoplasmic constriction. Am. Jour. Anat., vol. 16, p. 127 .

1914 Ibid. Anat. Record, vol. 8, p. 101.

1916 The cell clusters in the dorsal aorta of the mammalian embryo. Am. Jour. of Anat., vol. 19, p. 401.

Evans, H. M. 1914 The physiology of the endothclium. Anat. Rec., vol. 8, p. 99 .

Gabriet, S. 1908 Über Ringkörper im Blute An̋̈misches. Deutsch. Archiv. Klin., Med. Bd. 92, p. 602.

Goldmann 1912 Neue Untersuchungen über die äussere und innere Sekretion. etc. Tübingen.

Goodrich, E. 1899 On the Nephridia of Polychaeta. Part II. Quart. Journ. Micr. Sc., vol. 41, p. 439.

Gruner, O. C. 1913 The biology of the blood cells. Bristol.

HAFF, R. 1914 Bindegewcbe und Blutbildungsprozesse in der Embryonalen Leber des Huhns. Archiv. f. Mikr., Anat. Bd. 84, p. 321.

Hrs, W. 1901 Lceithoblast und Angioblast der Wirbelthiere. Histogenetische studien. Abhandl. der Math.-Phys. Classe Gesellsch. der Wisscnschaften. Bd. 26, p. 171.

Hooper, C. W. and Whipple, G. H. 1915 Icterus. A rapid change of hemoglobin to bile pigment in the pleural and peritoneal cavities. Proc. Soe. for Exper. Biol. and Med., vol. 13, p. 22. 
JoLI, J, 1907 Recherches sur la formation des globules rouges des mammiferes. Archives d'Anatomie, T. 9, p. 133.

JÜNGER, 1900 Uber Kernhaltige rothe Blukörperchen im Strömenden Menschlichen Blute. Deutseh. Archiv. Klin. Med. Bd. 67, p. 109.

Kyes, P. 1915 The physiological destruction of erythrocytes in birds. Internat. Monatsschrift J. Anat. u. Physiol., Bd. 31, p. 543.

LANG, A. 1904 Beiträge zu einer Trophocöltheorie. Jenaische Zeitschr. f. Naturwissench., Bd. 38.

Lippmann-Plesch 1913 Uber die Genese Der 'Lymphozyten' in den Exsudation seröser Höhlen von aleukozytären Tieren. Deutsche Med. Wochenschr. No. 29.

MacCurdy ANd Evans 1912 Experimentelle Läsionen des zentralnervensystems, untersucht mit Hilfe der vitalen Färbung. Berl. Klin. Wochensehr. No. 36.

MaLL, F. P. 1912 On the development of the human heart. Am. Jour. Anat,, vol. 13 , p. 249.

Maxrmow, A. 1909 Untersuchungen über Blut und Bindegewebe. I. Die frühesten Entwicklungsstadien der Blut-und Bindegewebezellen beim Säugetierembryo, bis zum Aufang der Blutbildung in der Leber. Archiv. f. Mikr. Anat. Bd. 73, p. 444.

Minot, C. S. 1912 The origin of the angioblast and the development of the blood. Keibal-Mall Human Embryology, vol. 2.

NAEGELI, O 1912 Blutkrankheiten und Blutdiagnostik. Leipzig.

Pappenheim-Fukushr 1913 Neue Exaudatstudien und wietere Ausführungen über die Natur der lymphoiden peritonealen Entzündungszellen. Folia Hacmat. Bd. 17, p. 257.

Scammon, R. E. 1915 The histogenesis of the selachian Liver. Am. Jour. Anat., vol. 17, p. 245.

Schleip, K. 1907 Über Ringkörper im Blute Anämischer. Deutsch. Archiv f. Klin. Med. Bd. 91, p. 455.

Schotт und WeidenReich 1909 Morphologische und experimentelle Untersuchungen über Bedeutung und Herkunft der Zellen der Serösen Höhlen. Arch. f. Mikr. Anat. Bd. 74.

SchUlte, H. W. 1914 Early stages in the vasculogenesis in the cat with especial reference to the mesenchymal origin of endothelium. Anat. Rec., vol. 8, p. 78 .

Szecsi, St. 1912 Experimentelle studien über serosa-exsudatzellen. Fol. Haemat. Bd. 13, p. 1.

Srecsi, St. and Ewald, O. 1913 Zur Kenntnis der Peritoneal exsudatzellen des Meerschweinchens. Folia Haemat. Bd. 17, p. 167.

Tschaschin, S. 1913a Über die Herkunft und Entstehungsweise der lymphozytoiden (leukozytoiden) zellen, der 'Polyblasten' hei der Entzündung. Fol. Haemat. Bd. 16, Archiv.

1913b Über die 'ruhenden wanderzellen' und ihre Bezeihungen zur den anderen Zellformen des Bindegewebes und zur den Lymphozyten. Folia Haemat. Bd. 17, p. 317. Archiv. 
Weidenrzich, F. 1903 Die roten Blutkörperchen. I. Ergebn. d. Anat. u. Entwicklungsgesch. Bd. 13.

1911 Blutkörperchen und Wanderzellen. Sammlung Anatomischer und physiologischen Vorträge und Aufsätze. Bd. 2, Helft 2.

1912 Die Thymus der Erwachsen Menschen als Bildungsstätte ungranulierter und granulicrter Leukozyten. Münchner Med. Wochenschrift. No. 48 , p. 2601. 


\section{PLATE 1}

\section{EXPLANATION OF FIGURES}

The following figures are from camera lucida drawings in all of which, with the exception of the low power drawing in 41 and in 1 to 7,11 to 13 , which were outlined with a No. 8 ocular, the details were drawn from observations with a Zeiss appochromatic immersion objective and No. 4 and 6 compensation oculars. Fifteen of the drawings were made by Herr Kretz, artist at the Anatomical Institute of the University of Strassburg and twenty-one by Mr. Jarrett and Miss Ehinger at the Anatomical Laboratory of the Washington University Medical School. In the reproduction plates 2 and 4 were reduced by one-fifth from the original drawings.

1,2 Cells belonging to the first of the three types described under coelomic macrophags. The cytoplasm is decidedly basophilie, contains a number of small cytoplasmic vacuoles and the nuclei are either round or kidney shaped. What appears to be a centrosphere is seen at the left of the nucleus in figure 1 . These cells are interpreted as coelomic macrophags in a stage of inactivity with reference to phagocytic functions. From the pericardial cavity of a $9 \mathrm{~mm}$. rabbit embryo (compare with fig. 9).

3. Mitosis in the type of cells shown in figures 1 and 2. From the pericardial cavity of the same embryo as above.

4, 6. Macrophags at a stage of active phagocytosis. The inclusions appear to consist chiefly of erythrocytic elements. The lighter cytoplasmic and nucleoplasmic stain as compared with 1 and 2 appears correlated with an advanced stage of phagocytic activities. $n$, is nuclear inclusion with a lighter stained central area. From the pericardial cavity of a $9 \mathrm{~mm}$. rabbit embryo.

7 Mitosis in a coelomic macrophag containing two large cytoplasmic vacuoles (cf. fig. 3 ). Pericardial cavity $9 \mathrm{~mm}$. rabbit embryo.

8 Two coelomic macrophags lying side by side and consequently subject to identically the same technique. They demonstrate the lighter nuclear and cytoplasmic stain in the cells at stage of greater phagocytic activity $b$ as compared with the less active cells $a$. In cell $b$ one of the inclusions still retains an unmodified remnant, in the form of a crescent, of the original basophilic material of the ingested nucleus. Pericardial cavity, $9 \mathrm{~mm}$. pig embryo.

9, 10 Furnishes a striking contrast in the cytological characteristics of a phagocytically active (10) and a phagocytically inactive cell (9). From the same source as figure 8 .

11 Coelomic cell (macrophag?) showing a highly vacuolated condition of the cytoplasm. Peritoneal cavity, $9 \mathrm{~mm}$. rabbit embryo.

12 Cells occasionally found in the coelomic cavities of rabbit embryos, showing a peripheral border of eosin staining material. Similar structures are also found in the mesenchyma where they undoubtedly represent degencrating hemoglobin containing elements. Pleural cavity, $9 \mathrm{~mm}$. rabbit embryo.

13 A macrophag undergoing mitosis in which the large digestive vacuole still contains a visible undigested remnant of the phagocytic inclusion. Pericardial cavity, $9 \mathrm{~mm}$. pig embryo. 


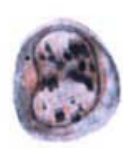

1

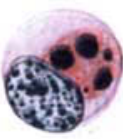

4

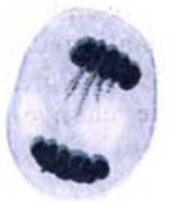

;

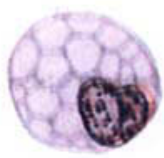

11

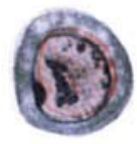

2

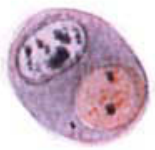

5

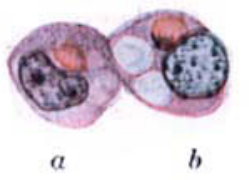

8

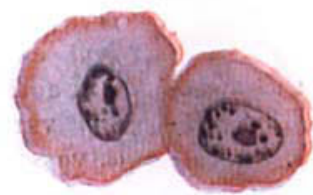

12

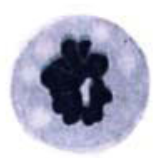

3

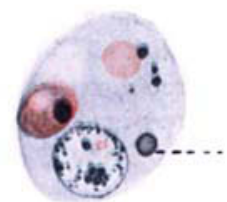

6
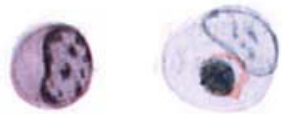

10 


\section{PLATE 2}

\section{EXPLANATION OF FIGURES}

14 One of fourteen sections through the pleuro-pericardial membrane of a $7 \mathrm{~mm}$. pig embryo. $c$, represents a central issue core surrounded by mesothelial cells (mes). Many of these cells have assumed a rounded form and are partially if not entirely detached from the main mass. These modified cells are phagocytically active $(\mathrm{pcm})$, contain cytoplasmic vacuoles $(v \mathrm{~cm})$ and present structural and tinctorial characters practically identical with that of typical macrophags. For general relations see figure 43. e, small eosin staining bodies (cf. figs. 20 to 26 ).

15 Free mesothelial cell masses in the pericardial cavity of a $9 \mathrm{~mm}$. rabbit embryo. The visceral and parietal pericardial walls, respectively, are at the right and left sides of the figure (mes).

16 Free mesothelial cell mass in the ventral region of the pericardial cavity of a $7 \mathrm{~mm}$. pig embryo. It extends through five sections, but in both this case as well as in figure 15 these cellular masses are at no point at tached to the coelomic wall. Some of the mesothelial cells are partially detached, present a rounded form and a slightiy more basophilic stain reaction $(m)$.

17 A region of the mesothelial surface showing a rounded, partially detached basophilic cell $(m)$ which appears to be a modified mesothelial cell. Visceral pericardium of a $9 \mathrm{~mm}$. pig embryo (cf. figs. $41,43,44$ ).

18 A group of free cells in the peritoneal cavity of a $9 \mathrm{~mm}$. rabbit embryo, interpreted in the text as degenerating erythrocytes. In some of the cells indications of hemoglobin are still evident $(a)$, in others the cytoplasm is paler in color show cytoplasmic vacuolation and degenerative nuclear changes $(b, c)$.

19 Other instances of degenerative nuclear and cytoplasmic changes in erythrocytes (cf. fig. 18). Peritoneal cavity, $9 \mathrm{~mm}$. rabbit embryo.

\section{ABBREVIATIONS}

$\mathrm{cm}$, coelomic macrophags

$d$, mitotic figures

icm, coelomic macrophags, apparently

in a stage of inactivity with refer-

ence to phagoeytic functions

in, phagocytic inclusions

$m$, rounded cells interpreted as meso-

thelial cells in the process of becom-

ing detached as free cells in the cot-

lomic activities $m c$, mesenchymal cells

mes, mesothelium

$\mathrm{mm}$, mesothelial cell masses found free in the coelomic cavities

pcv, pericardial cavity

pcm, coelomic macrophags in a stage of active phagocytosis

$v \mathrm{~cm}$, vacuolated coelomic macrophags w, vessel wall 


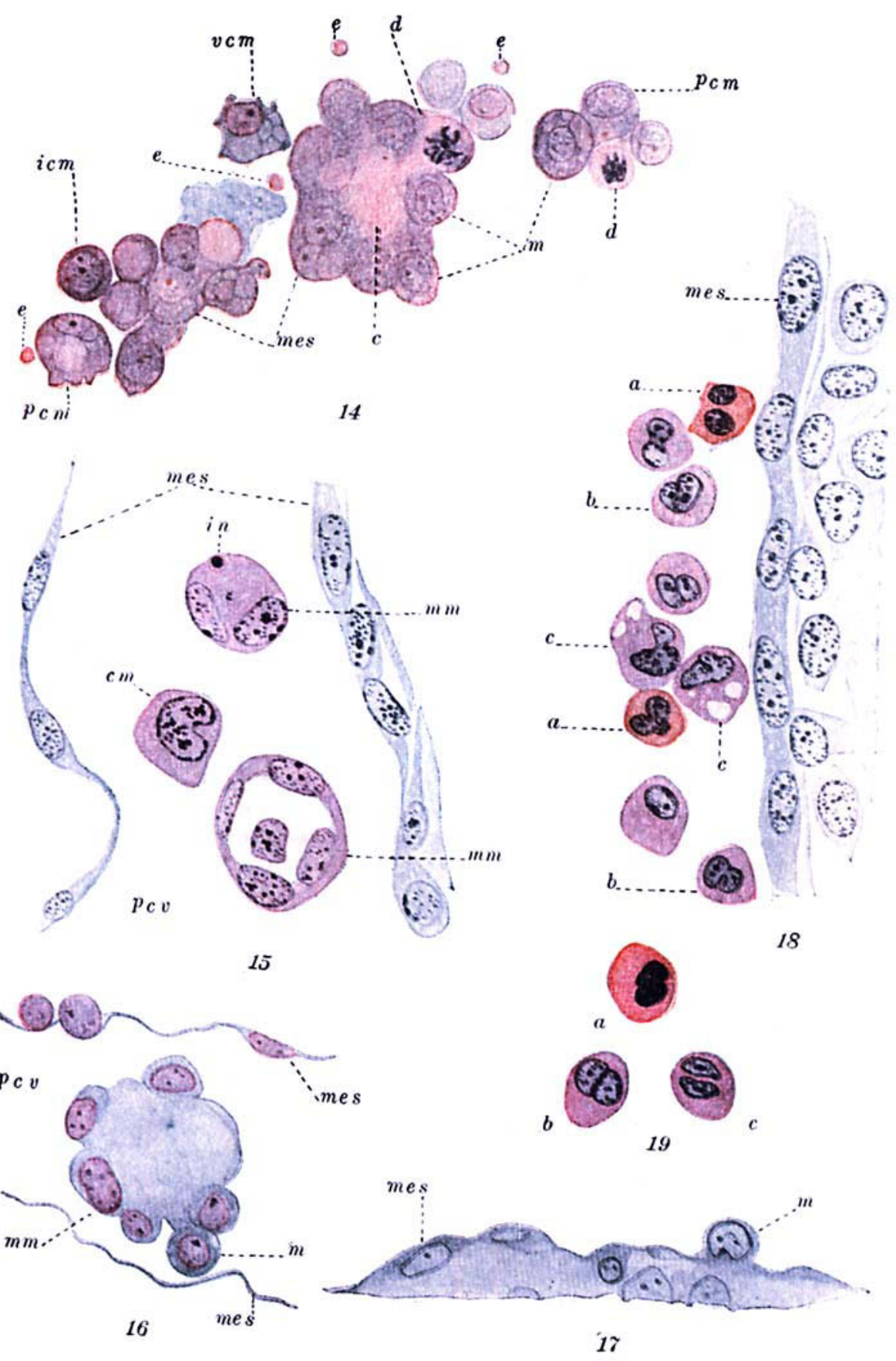




\section{PLATE 3}

\section{EXPLANATION OF FIGURES}

20 to 26 Small eosin staining bodies (degenerating erythrocytic nuclei) in the coelomic cavities, some of which contain variable quantities of basophilic material in the form of small spherules and peripheral rings. 20,22, 24, 26 are from the pleural cavities of $7 \mathrm{~mm}$. pig embryos; 21,23 from the pericardial cavity of a 13 day mouse embryo, and 25 from the pleural cavity of a $9 \mathrm{~mm}$. pig embryo.

27,28 Ring form structures (degenerating erythrocytic nuclei) in the tissue spaces. 27 is from the mesenchyma of the ventral thoracic wall of $9 \mathrm{~mm}$. rabbit embryo and 28 from the gasserian ganglion of a 13 day mouse embryo.

29, 30 Degenerating erythrocytic nuclei in the heart cavity of a $7 \mathrm{~mm}$. pig embryo (29) and of a 13 day mouse embryo.

$31,32,33$ Groups of small bodies, $e$ (degenerating erythrocytic elements consisting chiefly of nuclear material) in the embryonic tissues. 31 is from the mesenchyma of the ventral wall of a $9 \mathrm{~mm}$. rabbit; 32 from the mesenchyma the septum transversum of a $7 \mathrm{~mm}$. pig embryo; and 33 from the ventral wall of the fore-brain of a 13 day mouse embryo. Shows their variation in size, structure, stain reaction and intercellular relations.

34, 35, 36 Ring form nuclear structures (Cabot's rings) observed in degenerating erythrocytes found in the embryonic circulation. 34 and 35 respective$1 y$, are from a small blood vessel in the mesenchyma and a sinusoid in the liver of a 13 day mouse embryo; and 36 from a blood vessel (or posssibly lymphatic) in the mesenchyma of a $9 \mathrm{~mm}$. pig embyro.

37 Erythrocytes in the hepatic sinusoid of a 13 day rabbit embryo showing earlier stages in degenerative nuclear and cytoplasmic ehanges including lobulation of nuclei, hemolysis and cytoplasmic vacuolation.

38 Cells found in the intercellular tissue spaces of the mesenchyma of the same embryo as for figure 37 , concerning which grounds were advanced in the text indicative of their degenerating erythrocytic nature rather than leucocytic elements differentiating in situ from mesenchymal cells.

39, 40 Cells from the mesenchyma which appear in nuclear and cytoplasmic structure clearly intermediate between the cells shown in figure 38 and the degenerating erythrocytes in figure 37 . From the same source as figure 38 . 

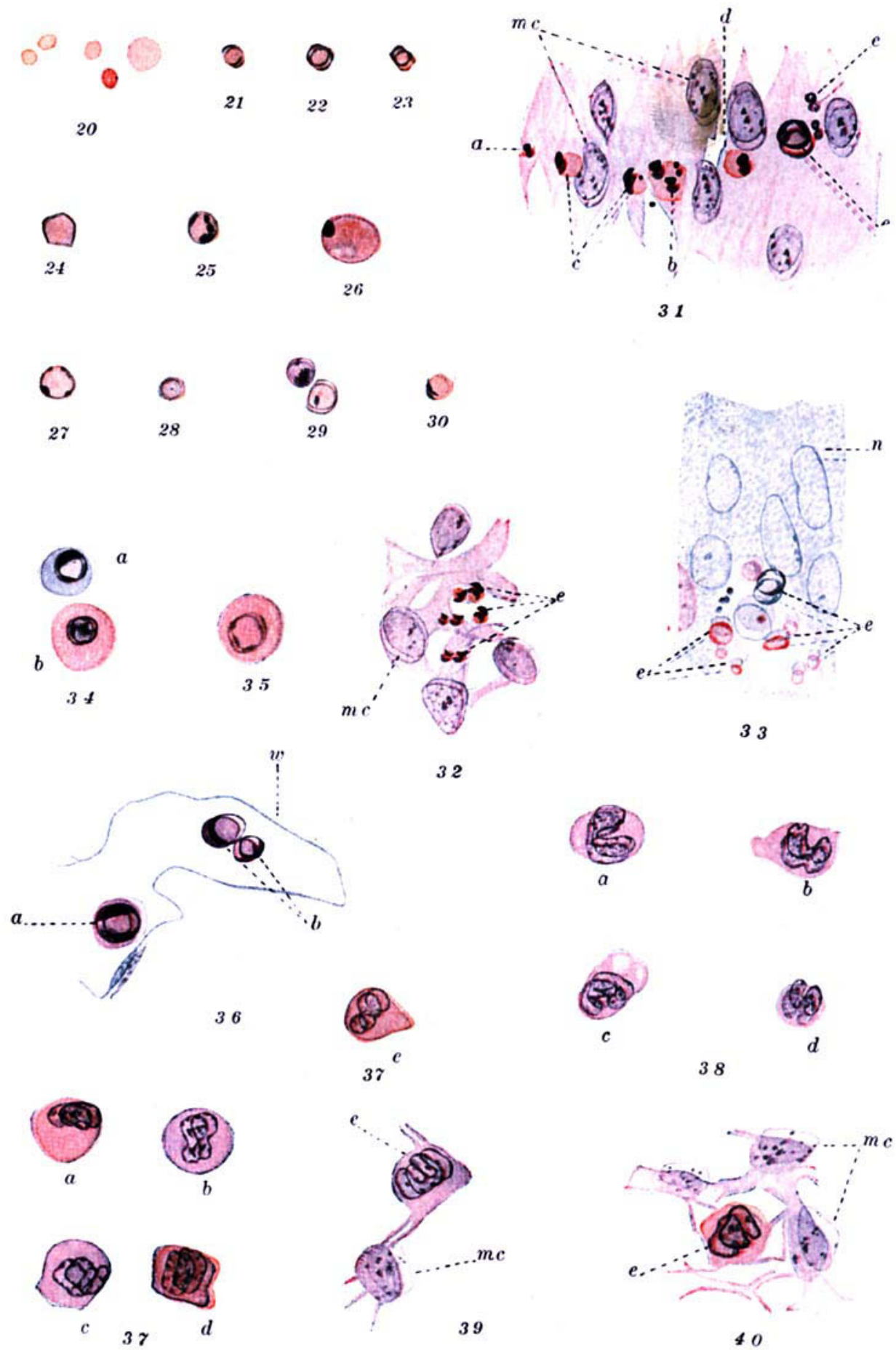


\section{PLA'TE 4}

\section{EXPLANATION OF FIGURES}

41 Showing a rounded cell $(m)$ projecting into the pericardial eavity from the visceral pericardium, but still attached by a slender cytoplasmic pedicle to the mesothelial surface. $7 \mathrm{~mm}$. pig embryo (cf. fig. $17,42,44$ ).

42 Demonstrating the potentiality for phagocytic activity on the part of the mesothelial cell. The mesothelial character of the cell can hardly be questioned, at the same time it is partially raised above the level of the mesothelial surface and the nucleus approximates a kidney-shaped form. From the parietal pericardium of a $9 \mathrm{~mm}$. pig embryo.

43 Showing the position and general relations of the section of the pleuropericardial membrane $(p p)$ drawn at a larger magnification in figure 14. It may be observed that the cellular mass in question lies in the pleural cavity (pcv) and that the latter is still in communication with the pericardial cavity through the pleuro-pericardial canal $(p p l c)$. The membrane continues through fourteen sections and is found to connect with the parictal wall at the junction of parietalpleural $(p p l)$ and parietal-pericardial $(p p c)$ walls where its cells become continuous with the mesothelium lining the coelomic walls.

44 Showing a region of the visceral pericardium in which the mesothelial cells present the appearance of transformation into free cellular elements. This region continues through several successive sections. Many of the cells assume a more basophilic stain than that of typical mesothelial cells, and phagocytic activities, cytoplasmic vacuolation and peripheral processes or buds (b) apparently identical with that of the coelomic macrophags. $7 \mathrm{~mm}$. pig embryo. 

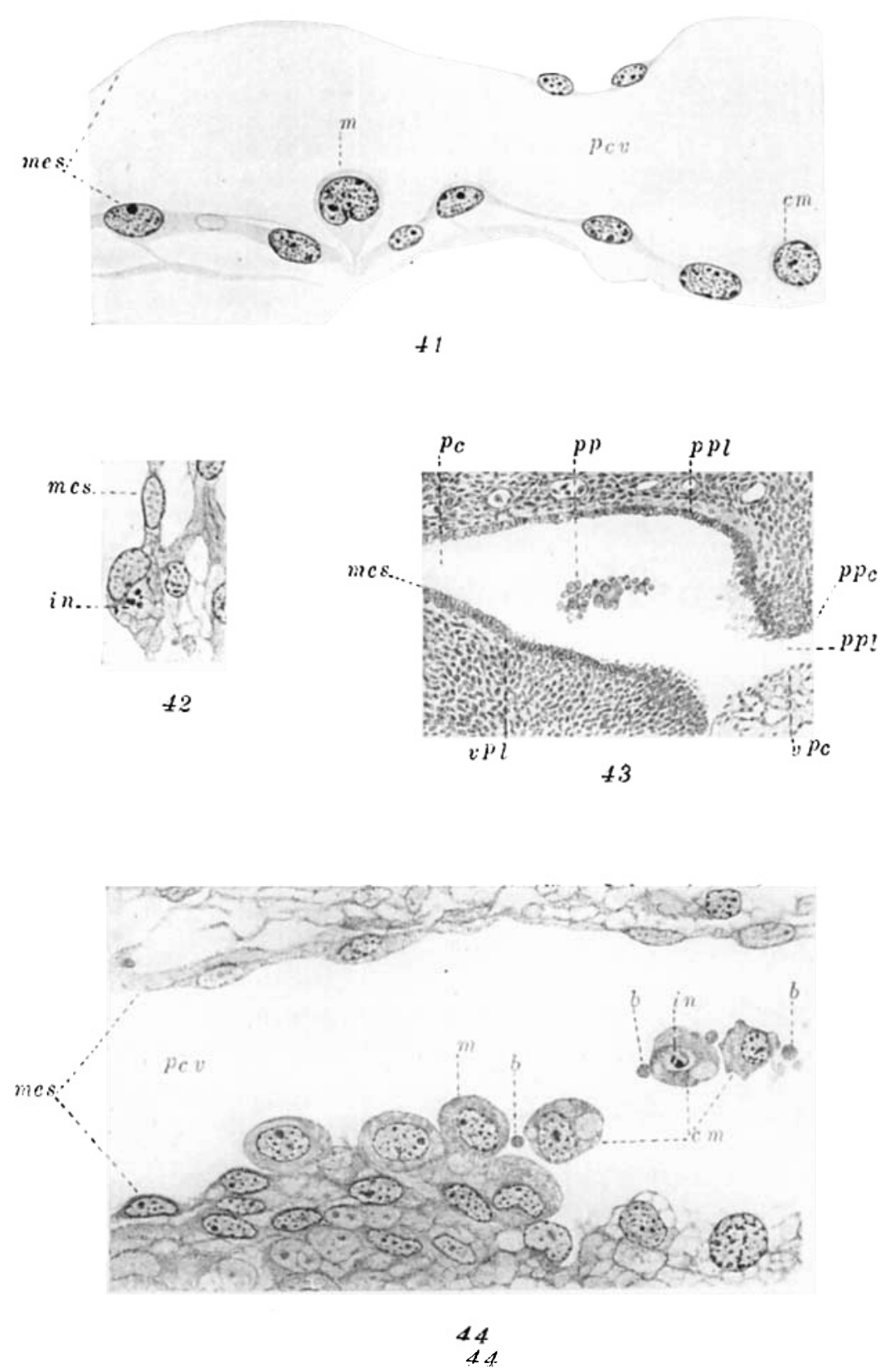

123 